\title{
ANALYSIS OF FACTORS INFLUENCING ONLINE CONSUMER BEHAVIOUR
}

\author{
Hovsepyan N.S. (YSU, Yerevan, Armenia) \\ hovsepyan_narek@yahoo.com

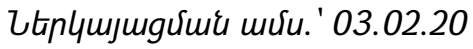

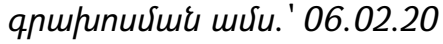

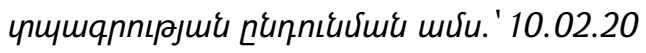

The purpose of this article is to discuss what factors influence consumer behavior and the factors, that online customer take into the consideration when purchasing online. For that we analyzed existing literature and went through the online purchasing process and identify the reasons why customers buy online and the barriers for online shopping.

After analyzing the literature, we identified that the main factors which consumers take into the consideration are price and convenience. At the same time trust in sellers, and the information they provide, is one of the major issues in the digital environment. Consumers constantly mention the perceived risks associated with using the internet. They believe that there is an additional risk of online fraud and scam.

Keywords: Behavior, person, online shopping, consumer behavior, online shopping influencing factors.

At the end of the 19th and in the beginning of the 20th centuries was formed a new term, which is known as marketing. Marketing was formed to study the supply and demand of the products and services in the market. It is a system of management, which studies the needs and wants of consumers, and the organization of production of these needs and wants. At the same time, marketing has affected the market and consumers' needs.

In the beginning the aim of marketing was the building the best sales force. At the end of the 20th century, with the technological changes, marketers started to focus on the individuals. The result of this was the change in marketers' job and responsibilities. With the appearance of the internet was created a new marketing emphasis. A new fast-paced digital economy is emerging in today's technology driven world, where the consumer is acting as an integral player in developing the products. As a result, was formed digital marketing, which allows vast coverage and helps serve customers better.

Usage of the internet by the consumer let the marketers advertise their products and "catch" their customers worldwide. Marketers started to use different 
types of techniques, in a digital environment such as search engines, social media, display advertising for achieving their goals. Marketers want to understand, consumers motivations and influences on them in the market for determining the right product for satisfying their needs and wants. It is worth nothing, to mention that identification of influencing factors is a very hard process. Very often consumer themselves can't understand what influenced them to buy a certain product or service. Kotler and Armstrong (2012) identify the main characteristics, which influence consumer behavior, which are cultural, social, personal, and psychological factors. It is impossible to control these factors but the marketers must take them into account [4].

Cultural factor with its three characteristic culture, subculture and social class is one of the main influences on consumer behavior. Subculture (formatted groups of people sharing the same values) and social class (social factors are income, age, education...) are very important for targeting right customer groups [4].

As a characteristic of personhood, factor age and life cycle stage are very important influences. With the age and life stage, consumers change his or her wants with this also changes their behavior. Occupation as a rule has influence on the consumer, what products and services to buy. Marketers try to identify the occupational groups that have an interest in their products and services or they are developing products for that group. The economic situation influences the consumer product choice. Consumers are sensitive to price or not, it depends on the level of their income, level of savings and also the product or service itself. The activities, interests, and opinions that person has, creates his or her lifestyle. This explains the way that consumer acts in the market [4].

According to Kotler and Armstrong (2012) personality is described by the terms self-confidence, dominance, sociability, autonomy, defensiveness, adaptability and aggressiveness. These factors have been created in a result of a person's contact with the environment. Self-concept is the understanding that person's possessions reflect his or her personality. These are very important, because brands also have personalities and consumers buy brands which matches to their personalities [4].

Consumer behavior is influenced by certain psychological factors: motivation, perception, learning, and beliefs and attitudes.

Motivation is one of the needs that people must satisfy. There are different kinds of needs: biological (hunger, thirst, discomfort etc.) and psychological (need for recognition, esteem and belonging). Needs must reach to a certain point of intensity to be satisfied. Needs have to become a motive for the consumer to satisfy them. When a person is motivated, he starts acting, and it depends on the level of a person's perception of the situation. Perception is the characteristic with which we study how differently people perceive the same situation or the same stimuli. 
Perception is the process by which people select, organize, and interpret information. The result of acting is learning. Learning is the change in a person's behavior because of their experiences. It occurs through drives, stimuli, cues. Drives are strong internal wants that call for action. Stimuli are the object that drives for a certain action. Cues are small stimuli that determinate when, where and how the person will respond and reinforcement. Because of acting and learning, people make for them beliefs and attitudes. These factors influence the buying behavior by making up brands and product images in the consumer's consciousness. Belief is a descriptive thought that a person has about something which can be based on real knowledge, opinion, or faith. It can be charged emotionally or non-emotionally. People have their own attitudes regarding everything like religion, politics, clothes, music, food [4]. Attitudes make people to like or dislike things.

A study of EU consumer behavior in the digital environment, pointed out that online shopping behavior refers to the process of purchasing products or services through the internet and this process consists of five steps. Accessing information, assessing and analyzing information, acting of assessment and analyses of information, complaints and remedies and non-complaints related post sale interactions [6]. Depending on the nature of the good or service, the importance of a particular stage and its duration can be different.

The rational consumers firstly will search for information about the product or service that want to buy. In this stage consumer can be affected by many factors. The study found out that improved access to information about products, services and prices has been shown to have positive benefits for consumers. At the same time, there is a problem for the consumers connected with the information overload. According to different surveys the difficulty of processing all the available information, limits consumer search. The search engine usage is very high globally. When searching online search engines are used by the consumers more than manufacturer websites, comparison websites and discussion forums. As studies have shown, there is a so-called Googlization of online searches. For many consumers, Google and the internet are essentially the same thing [6].

There are many reasons why people shop online. For examples, consumers can buy anything at any time without going to the store; they can find the same product at a lower price by comparing different websites at the same time; they sometime want to avoid pressure when having a face-to-face interaction with salespeople; they can avoid in store traffic jam, etc. These factors can be summarized into four categories-convenience, information, available products and services, and cost and time efficiency [2].

Surveys conducted by several researchers showed that some customers use online channels just to escape from face-to-face interaction with salesperson 
because they pressure or uncomfortable when dealing with salespeople and do not want to be manipulated and controlled in the marketplace. This is especially true for those customers who may have had negative experience with the salesperson, or they just want to be free and make decision by themselves without salespersons' presence [2].

Consumers' second step is to assess and analyze the information they found. In this stage consumer analyze the information in more narrow consideration and makes decisions, which type of product or service to buy and from which seller. "Consumers form reference points during the search process and the first product or seller viewed as part of the search process is likely to serve as the consumer's reference point for the remainder of the search"[6 pg. 68].

One of the major issues in the digital environment is trust in the information that suppliers provide. Because of this issue, consumers prefer to buy brands through the internet for overcoming this problem. For the consumers most trusted sources of information, which have been shown to influence consumer behavior, are recommendations and consumer reviews.

Another study of online consumer behavior in Singapore found out, that usage of the Internet as a tool, for information gathering purposes is extremely popular there (97\%) [8]. However, not all the consumers making purchase online after searching information in the internet. The percentage among the respondents that never made online purchase was very low.

Many consumers use price as an only mean for sorting online information when buying online, even if they have comfortable filtering mechanisms, which allow them to filter at the same time, on several different parameters, like price, time of delivery etc. A controlled experiment testing was conducted in 2010 about the effect of different price frames, which analysis showed that, drip-pricing, timelimited offers and baiting pricing all have an impact on consumer decision-making. There is an impact of advertising, on consumers' decision-making process also [6]. If consumer exposed to an advertisement in different websites, than in one, probability that he or she will buy is becoming high [5]. The framing and clarity of advertisements affects consumers' ability to analyze the information presented to them. The next stage for the consumers, after assessing and analyzing information is purchasing process.

When purchasing online convenience and the potential to save money where recognized as the main motivators for the consumers. Consumers benefit from online shopping by paying lower prices, accessing to a wider variety of goods and sellers, increased ease of comparing product specifications and prices. There is also greater convenience of online shopping and greater ability to receive consumer information on consumer forums. According to the survey made in 2010 in EU, 
$50 \%$ of EU consumers feel more empowered in the online environment, because they think that have better access to better products choice online [6].

According to Sen (2014), who studied online shopping and factors influencing online purchases of products in Kolkata, find out, that the most influencing factor on the consumers was lower price. Lower price is very attractive for the consumers to make purchases online. They have a chance to purchase the same product in lower price online. Discounts and other sales promotional techniques attract customers to purchase the products online [9].

The second factor that was identified is convenience. The customers focus on the convenience of shopping online, as compared to the traditional form of shopping . Customers find it much more convenient to shop at home, and it also saves time [9].

There are many consumers, who avoid from online shopping. The most part of these consumers say that they prefer to buy in person, because they want physical experience and personal contact only available from offline shops. The perceived risks may act as a barrier for online shopping in Europe, particularly for cross-border online shopping [6]. Security, privacy and trust concerns are common barriers for online shopping. Consumers also take into consideration, the stories that they heard about online shopping, like online scams or non-delivery of products purchased online. In addition, the shopping limitations and financial risks are the two main inhibitors for the consumers who don't want to buy online [1].

TNS Opinion and Social (2011) reported, that nine out of ten EU consumers who have shopped online have provided their name and $89 \%$ have provided details of their address. Moreover, $45 \%$ have provided their mobile phone number, $35 \%$ details of their nationality and $33 \%$ have provided financial information [10]. It is important to mention, that for online transactions, at least the provision of the consumer's name and address will be necessary for delivery of the goods or services that the consumer bought.

Fifty five percent of EU online consumers consider that the risk of fraud with disclosure of personal information is one of the most important risks [6]. In addition, $43 \%$ of online consumers are also worried that the information will be used without their knowledge and permission and 35\% have fear, that they will become victims of identity theft [10].

These online shopping barriers make consumers to search for the products and services online, but make purchases offline. The main reasons for leaving a website without purchasing are that consumers want to see the actual product before buying; they are not sure that the site provides the best price; they find shipping costs too high; they don't like to register before purchasing the product and they don't find the desired product [6]. 
The consumers appear at the stage of complaints and redress, when they have a problem with the product that bought. Consumers may experience a problem incurred, related to delivery or the quality of the product or service in the digital environment. Problems related to quality can be connected with misleading information. At the same time, consumers mention, that return policies and communication with the traders are more important for them, then the lack of product information for buying online [6]. With this, consumers want to be sure, that if they will have problem with non-delivery and quality of the product or service, they will be able to contact with suppliers and solve that problem.

Problems with online scams and fraud are also very common. One of the examples of that is subscription traps4. Similarly, there are examples of consumers receiving what appear to be personal messages and are asked to enter personal details to find out who sent them [6]. After doing that, consumers later found out that they had entered into a contract. The largest share of the consumers don't know how to complain about this problem.

The consumers, when deciding complain or not, take into consideration a number of factors. Kim, et al. (2003) suggests that for consumers, it may depend on the value of complaining and the likelihood of success [3]. Another factor for the consumers is that they can give their complaint effectively to an authority who will handle their complaint well [7].

Other factors include consumer characteristics and the type of sector of the product. For example, consumers are more likely to complain if they have experience of a product or service or if they have a higher purchase frequency. The consumers who are ready to expend non-monetary resource, such as time and effort, for obtaining products and redress, have a higher propensity to complain. Moreover, if the product is in a competitive market, where substitute products exist, consumers can easily switch to other substitute product, if they are dissatisfied [6].

Muller et al. the 2011 study found out that online customers are less likely to complain, compared to offline consumers even if, they were in a similar situation, as offline customers were. Online customers are more sensitive to the benefits and costs of making a complaint. Moreover, they are more sensitive to delays by the seller in responding to their complaint. The survey results pointed out, that the main frustration for complaining online customers is the poor communication levels they may encounter with online traders. Consumers, who have purchased online, have problems, with the poor communication levels with online traders. Online traders do not answer emails or respond to phone calls, which leaves consumers in

\footnotetext{
${ }^{4}$ Subscription traps are websites that offer services that are free but contain hidden or difficult to find clauses that constitute a purchase contract/subscription that comes into effect when the user provides personal information.
} 
a poor position in terms of obtaining redress. $72 \%$ of UK internet shoppers thought that the problems were harder to resolve when shopping online [6].

Conclusion

One of the benefits for the consumer, when purchasing online is the price. Consumers may buy the same product in the online environment at a lower price. The reason of this is lower transaction costs. Another reason for the lower price are increased competitive pressures in online environment. According to the literature, that we studied consumers are more likely to buy, when the price for the product is lower, than in an offline environment. Thus, the price is one of the main factors, which consumers take into consideration when buying online.

Consumers prefer to purchase online, because of convenience. Internet environment lets them make purchase 7 days in a week and 24 hours a day. It makes possible for the consumers to buy products from domestic market, at the same time to make a purchase from cross border markets. It is worth noting, that consumers can find better deals online than offline, because of access to a large variety of products. It is also important, that they are able to find a product online, which more closely matches their preferences. Internet environment gives ability to consumers compare product specifications in easy way. They can get product information at very low cost. Consumers are able to get information about other consumers' experiences in the online environment and receive information about online sellers and the products, that other consumers bought before. Price comparison websites let consumers to compare the prices of the products or services, which they want to buy. It gives a chance to internet shoppers, easily to find the best deal for them. When consumers use all these tools, that suggests online environment, they save time. This is very important for the consumers, who have not enough time to search of the products offline.

Trust in sellers, and the information they provide, is one of the major issues in the digital environment. Consumers say that they don't trust the information, about the quality of products, which sellers provide. That is the reason, why consumers give so much value to brands, when buying online. At the same time exists another issue about the forgery brands. Consumer trust in advertising information is also low.

Consumers constantly mention the perceived risks associated with using the internet. They believe, that there is an additional risk of online fraud and scam. When consumers purchase in the digital environment, they mention, that they had problems related to the delivery or quality of the product or service. According to consumers the main frustration for complaining online customers is the poor communication levels, they may encounter with online traders. A common problem appears to be, that online traders choose not to answer e-mails or respond to phone calls, which leaves consumers in a poor position in terms of obtaining 
redress. Another issue for the consumers in the digital environment is providing of personal data. Consumers have fear, that the sellers will use their personal information or they will give it to the third side.

\section{References}

1. Anckar, B. (2003). Drivers and inhibitors to E-commerce adoption: exploring the rationality of consumer behavior in the electronic marketplace.

2. Katawetawaraks C., Lu Wang C. Online Shopper Behavior: Influences of Online Shopping Decision// Asian Journal of Business Research, Vol. 1, N 2 , 2011// https://swsu.ru/sbornik-statey/pdf/Online\%20Shopper\%20 Behavior\%20Influences.pdf [Accessed 02 Feb. 2020].

3. Kim C., Kim S., Im S., and Shin, C., (2003). The effect of attitude and perception on consumer complaint intentions. Journal of Consumer Marketing, 20(4), pp. 352-71. . Available at: https://www.researchgate.net/ publication/235261232_The_effect_of_attitude_and_perception_on_consum er_complaint_intentions [Accessed 02 Feb. 2020].

4. Kotler P. and Armstrong, G. (2012) Principles of Marketing, (14th edition), Upper Saddle River, Prentice Hall.

5. Manchanda P., Dubé, J-P, Goh, K.Y., and Chintagunta, P.K., (2006). The Effect of Banner Advertising on Internet purchasing. Journal of Marketing Research, 43(1). pp 98-108

6. Muller P., Damgaard M., Litchfield A., Lewis M. and Hörnle, J. (2011). Consumer behavior in a digital environment. Study [pdf] Brussel: European Parliament. Available at: http://www.europarl.europa.eu RegData/etudes/etudes/join/2011/464441/IPOL-IMCO_ET(2011)464441_EN. pdf [Accessed 02 Feb. 2020].

7. Ong C.E., and Singh M., (2009). The Role of Redress in B2C E-business. BLED 2009 Proceedings. Available at: https://pdfs.semanticscholar.org/105a/ef0a919ff1129da7b2827c501d5d882 9dd22.pdf [Accessed 02 Feb. 2020].

8. Sam C.Y., \& Sharma C. (2015). An Exploration into the Factors Driving Consumers in Singapore towards or away from the Adoption of Online Shopping. Global Business and Management Research: An International Journal, 7(1), 60-73. 
9. Sen R. A. (2014) Online Shopping: A Study of the Factors Influencing Online Purchase of Products in Kolkata.International Journal of Management and Commerce Innovations. Vol. 2, Issue 1, pp: (44-52),

10. TNS Opinion and Social, (2011). Special Eurobarometer 359: Attitudes on Data Protection and Electronic Identity in the European Union. Available at: http://ec.europa.eu/public_opinion/archives/ebs/ebs_359_en.pdf [Accessed 02 Feb. 2020].

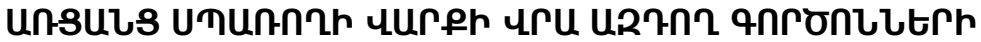

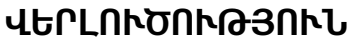

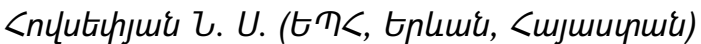

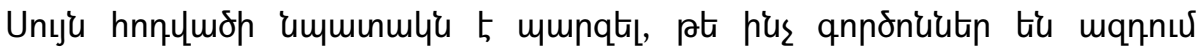

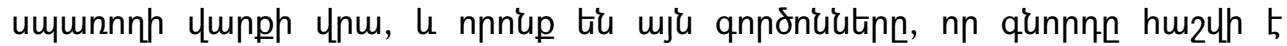

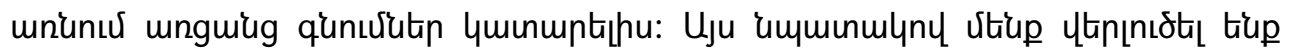

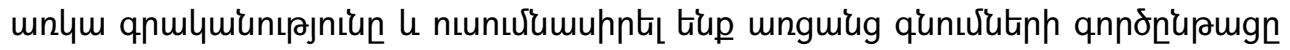

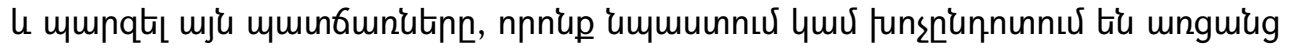

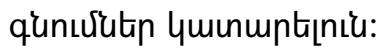

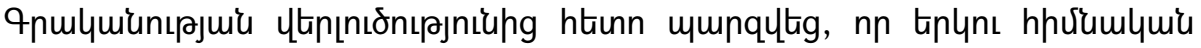

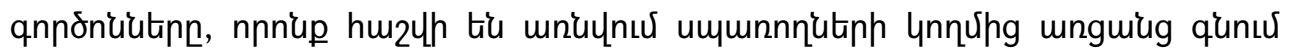

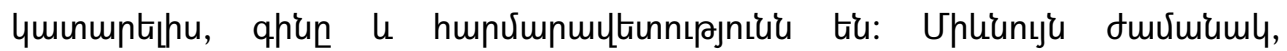

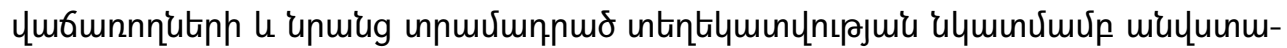

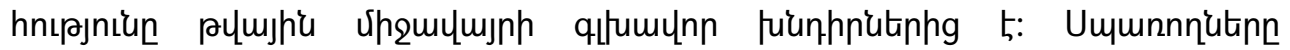

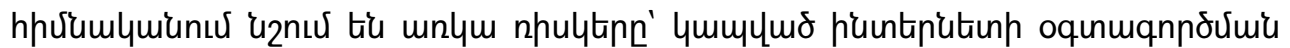

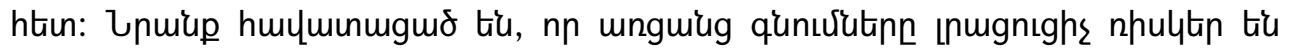
uuntindnuर्u pntiug huxump:

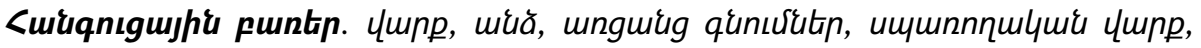

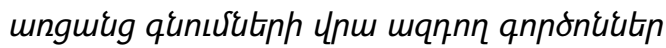

\section{АНАЛИЗ ФАКТОРОВ ВЛИЯЮЩИХ НА ПОВЕДЕНИЕ ОНЛАЙН ПОТРЕБИТЕЛЯ}

Овсепян Н. С. (ЕГУ, Ереван, Армения)

Целью данной статьи является рассмотрение различных факторов, влияющих на поведение потребителей, в результате сопоставления которых клиент принимает решение о совершении покупок в Интернете. Для этого мы проанализировали существующую литературу, прошли процесс онлайн-покупок и выяснили причины, по которым клиенты покупают онлайн, и барьеры для покупок в интернете. 
По результатам анализа литературы было выявлено, что основными двумя факторами, которые потребители учитывают, являются цена и удобство. В то же время доверие к продавцам и информация, которую они предоставляют, является одной из основных проблем в цифровой среде. Потребители постоянно упоминают о предполагаемых рисках, связанных с использованием Интернета. Они считают, что существует дополнительный риск мошенничества в интернете.

Ключевые слова: поведение, личность, покупки в интернете, потребительское поведение, влияющие факторы. 